\title{
$\mathrm{X}$ 線と computed tomography による胸部食道癌の
}

\author{
他臓器浸潤の診断に関する研究
}

\author{
東京女子医科大学消化器病センター外科（主任：羽生富士夫教授） \\ 杉山明德
}

\section{STUDY ON THE DIAGNOSIS OF THE INVASION INTO THE NEIGHBORING STRUCTURES OF THORACIC ESOPHAGEAL CARCINOMA BY X-RAY AND COMPUTED TOMOGRAPHY}

\author{
Akinori SUGIYAMA \\ Department of Surgery, Institute of Gastroenterology Tokyo Women's Medical College
}

(Director : Prof. Fujio Hanyu)

\begin{abstract}
胸部食道癌128例に対し食道 X線検査と computed tomography（以下 CT）検查を施行し; 他臓器 浸潤の診断を行った，X線診断とCT 診断を組み合わせて診断を行らことにより正診率は，overall accuracy $98.6 \%$, specificity $99.4 \%$, sensitivity $88.9 \%$ と診断能の向上をみた。とくに大動脈に関し ては両者の総合診断が有用であった，気管・気管支に関しては食道X線検査は診断能の高い検査法で あった。一方 CT 検查は浸潤の程度を知る上で有効な検査手段であった。，心のうに関しては心拍動な どの影響で sensitivity が $66.7 \%$ と他の臓器と比べ正診率は劣った。本検查法は簡便で poor risk の食 道癌症例の他藏器浸潤の診断に有用な検查法と考えられた。
\end{abstract}

索引用語：食道癌, 食道X線検査, 食道 computed tomography 検査, 食道癌の他臓器浸潤

\section{I. 緒 吾}

術前に食道癌のリンパ節転移や他臟器浸潤（以下食 道癌取扱い規約 ${ }^{11}$ に従い $\mathrm{A}_{3}$ と略す) の有無を知ること はその手術適応や術式の選択, 術中リンパ節郭清など の点で重要である2) 9). 最近における内視鏡的超音波 検查や computed tomography (CT) 検査などの新し い検查法の診断技術の向上に伴い，術前に得られる情 報は豊富になってきた。とくに超音波検查による肝転 移や頸部・腹部リンパ節の腫大の有無 ${ }^{10)}$, 内視鏡的超音 波検查による胸腔内リンパ節の腫大の有無や壁深達度 についてなど"1180\%以上の正診率で術前診断が可能と なってきた。

しかし，われわれが遭遇する胸部食道癌の約 $20 \%$ は 周囲臟器への漫潤を認める症例である2) ‘)。このよう な $\mathrm{A}_{3}$ 食道癌に対し, 食道造影年 2 15) 户内視鏡検查 ${ }^{16177}$

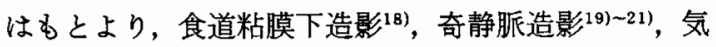

$<1986$ 年 9 月 3 日受理 $>$ 別刷請求先：杉山 明徳 于317 日立市若葉町 $1-4-5$ 志村胃腸科外科病 院
縱隔撮影，胸管造影などが試みられ， $\mathrm{A}_{3}$ の診断能の向 上をはかるべき努力がなされてきた。しかし，一般に 食道癌患者は高龄で poor risk 症例が多く, 術前検查 も多く，また術前合併療法も必要であり，できる限り 侵襲の少ない検査法で $\mathrm{A}_{3}$ の診断ができることが望す しい.CT 検查は non invasive な検査法であり, 現在 ではルーチン検査として行われるようになり，また CTKより食道癌と周囲臓器との解剖学的位置関係が 客観視できるようになった。

$\mathrm{A}_{3}$ 食道癌のらち, 症例によっては局所進展が著しく 周囲藏器にまで浸潤が及んでいながらす遠隔転移の認 めない症例むあり，このような症例では積極的に大動 脈や気管・気管支などの合併切除を行觉ば, 根治手術 が可能となる。最近では根治手術を目的とした大動脈, 気管などの合併切除が行われるようになり9),より正 確な $\mathrm{A}_{3}$ の診断が求められるようになってきた.

今回，簡便でかつ特殊な手技を要さない食道X線検 查と CT 検査とによる診断が，術式の選択や合併切除 の適応の決定に重要である $\mathrm{A}_{3}$ の術前評価に応用でき 
れば有用であると考㐫本研究を行った。つまり，従来 のX線診断と CT 診断を組合わせて新しい診断基準を 作成し臨床的検討を行った。 その結果これらの診断の 有用性についていささかの知見を得たので報告する。

\section{II. 検索対象ならびに方法}

\section{1. 検索対象}

対象は 1983 年 6 月より 1985 年 3 月までの期間に入院 した食道癌患者178例のらち, 他藏器浸潤についてて検討 がなされた胸部食道癌症例128例である.このらち切除 し完た症例は126例で, 残りの 2 例は bypass 手術之 なった。

症例の内訳は，男性112例，女性16例で平均年跲は 60.3歳（35歳～81歳）であった。

\section{2. 検索方法}

使用した CT 装置は東芝70Aで，スキャン時間は 4.5 秒, スライス幅は $10 \mathrm{~mm}$ で, 鎖骨上窝から下部食道 まで22 25スライスし，ほぼ全例に水溶性ヨード剤で ある60\%Conrayを投与した. 投与方法は $100 〜 150 \mathrm{ml}$ を末梢の静脈より, はじめ $30 \mathrm{ml}$ 程度を急速点滴静注 し, その後1.5 2.0ml/sec の速度で適宜ボーラス注入 した。 原則的には経口からの造影剤の投与は行わな かった. 交写真は 4 倍に払大し読影, 診断を行った。

な拉, 食道癌の部位, X線型, リンパ節の名称や分 類などは食道癌取扱い規約 11 亿従い以下の統計学的評 価は sensitivity, specificity, overall accuracyの criteria ${ }^{22)}$ に基づいた。

\section{III. 診断基準の作成}

まず食道X線像より癌腫の壁在性や部位, 潰瘍の深 さ, 周堤の高さ, 狭窄の程度, 発育伸展方向などを検 討し, その上で CT 像から癌腫の横への広がりの程度 や他藏器との関係を読み, 術前診断を行った（表 1 ).

大動脈に関しては, 以前より癌腫との low density の有無, 癌腫との接触の程度などが診断根拠 ${ }^{23)}$ の心 であったが，これまで CT 上広範囲にわたり癌腫が大 動脈之接している所見を呈しながら，術中全く浸潤を 認めなかった症例を経験し, 癌腫の浸潤を思わせた factorを retrospective に検討した。 局所の小リンパ 節群, 肥厚した胸膜, 結合織, 大動脈の mural thrombosisさらには大動脈自身の拍動やPartial volume effect などの影響がそれらに関与していると思われ， 癌腫が大動脈に直接浸潤を認めるためには, 癌腫が Im 中心であり全周性の狭窄を示す漏斗型やらせん型か左 〜後壁に大きな潰瘍をるつ鋸歯型であることが前提 で,さらにCT 像で癌腫が大動脈と大動脈の $1 / 4$ 周以上
表 1 他臓器浸潤の診断基準

大動脈に関して

(1) 食道 $\mathrm{X}$ 線像

主要占居部位が Im で全周性か左後壁中心であ る.

(2) CT 像

大動脈と癌腫の接する面が, 大動脈の $1 / 4$ 周以 上である。

気管に関して

(1) 食道 $\mathrm{X}$ 線像

主要占居部位が Iu で全周性か前壁中心で，気

(2) CT 像 管への圧排を認める.

気管と癌腫の接する面が気管の $1 / 3$ 周以上で癌 腫が気管内へ突出している。

気管支に関して

(1) 食道 $\mathrm{X}$ 線像

気管分岐部付近で軸偏位を認める。おたは, Im で全周性か前壁中心の癌腫で少なくとも周堤が Iuにかかっている.

(2) CT 像

湶腫による気管支壁の著明な圧排や不整，狭細 化，直線化を認める。

心のらに関して

(1) 食道 X楾像

(2) $\mathrm{CT}$ 像 全周性や前壁中心の癌腫である。

心のらが強く压排され，その辺縁が不整である。

図 $1 \quad a_{2}$ 食道癌症例. CT 上は癌腫が大動脈の $1 / 3$ 周以 上 (矢印の範囲) 接していて $\mathrm{A}_{3}$ のよらとみ兄るがX 線上での漬䇛の深さや周堤の性状からは $\mathrm{A}_{3}$ は考克 にくい.

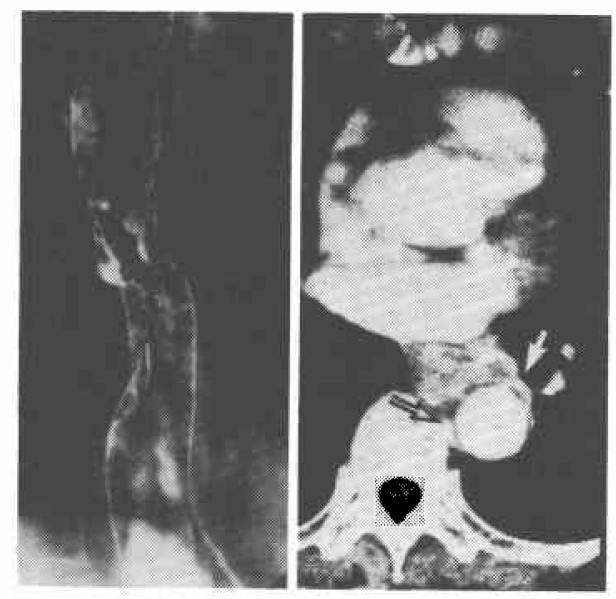

接していることが $\mathrm{A}_{3}$ の診断に重要であると考えた(図 $1,2)$.

気管に関しては，CT 像で癌腫と気管との接する面 
図 $2 \mathrm{a}_{3}$ 食道癌症例. Im 長さ $8 \mathrm{~cm}$ のらせん型でX 線 上でもCT 上です大動脈への浸潤が疑われる。
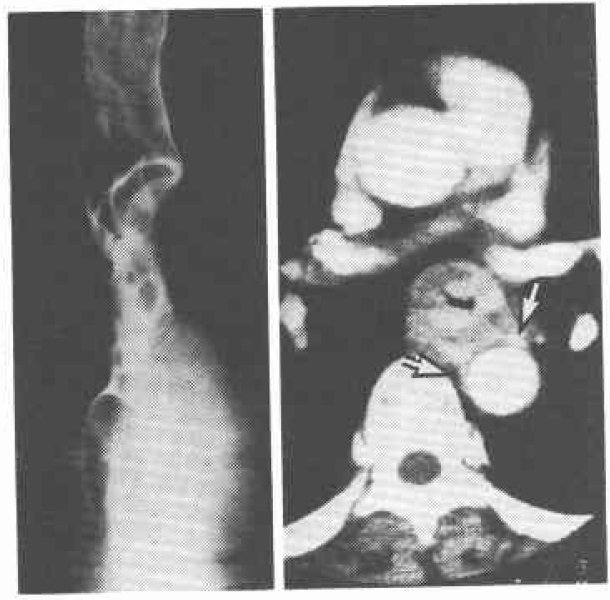

困 $3 a$ : Iu 漏斗型の食道癌で, 癌腫による気管の変 形 (矢印)をみる $\mathrm{a}_{2}$ の症例である。 b:Iu らせん型の 食道癌で, 癌腫が気管内腔へ突出 (矢印) している $\mathrm{a}_{3}$ の症例である。 a

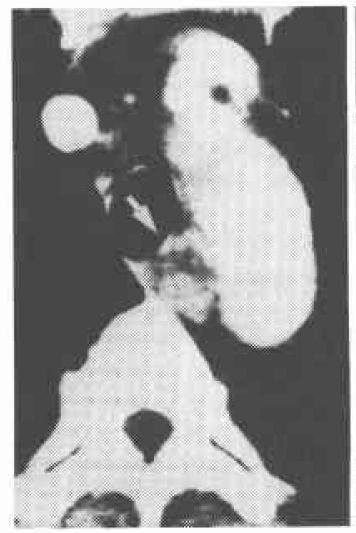

b

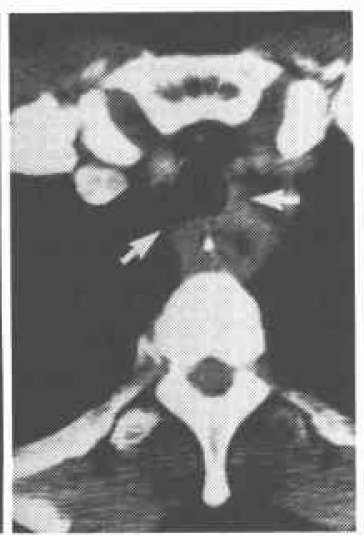

の大きさよりも癌腫が気管内腔へ凸状に突出している ことを最も重要な $\mathrm{A}_{3}$ の診断根拠とした（図３）.

気管支に関しては，X線像にて軸偏位を認めるもの や前壁に深い潰瘍をもつもので CT 像にて癌腫による 気管支壁の著明な圧排や不整を認めるもの,さらに CT 上気管支壁に癌腫による狭細化，直線化をみるも ののうち，X線像で癌腫が Im から Iu K及んでいるも のを $\mathrm{A}_{3}$ と診断した（図 4, 5).

心のらに関しては，CT上心のらが強く王排され，そ の辺縁が不整であること, motion artifact の消失など を $\mathrm{A}_{3}$ の診断根拠とした（図6).

図 $4 \mathrm{ImIu}$ らせん型の食道癌でX線上軸偏位を認め る $\mathrm{a}_{3}$ 症例である.CT 上では左気管支壁の直線化（矢 印）を認める。

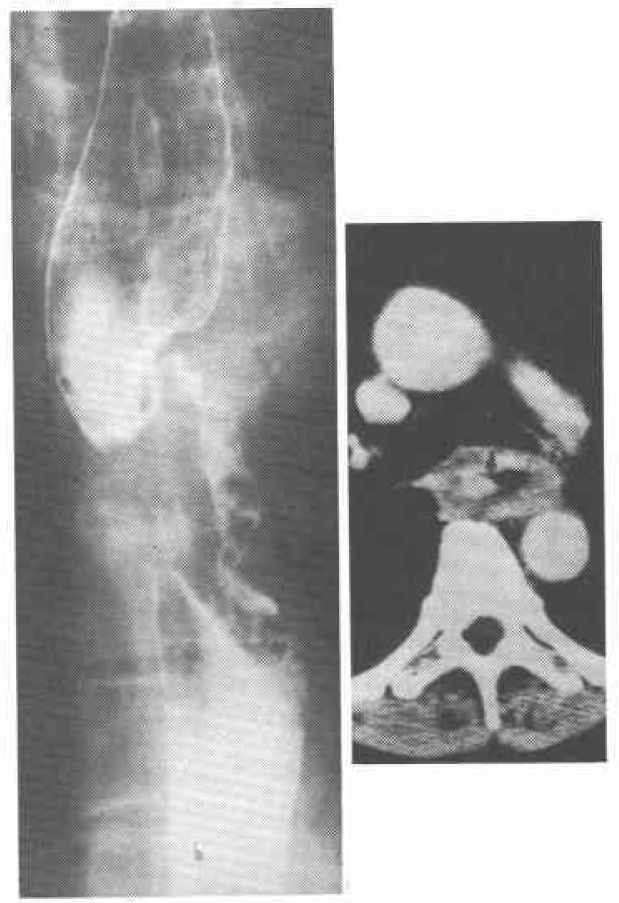

図 $5 \mathrm{a}$ : 気管支壁の著明な不整像（矢印）を認める. $\mathrm{b}$ : 気管支壁の著明な压排像 (知印)を認める。いず れも $a_{3}$ であった。

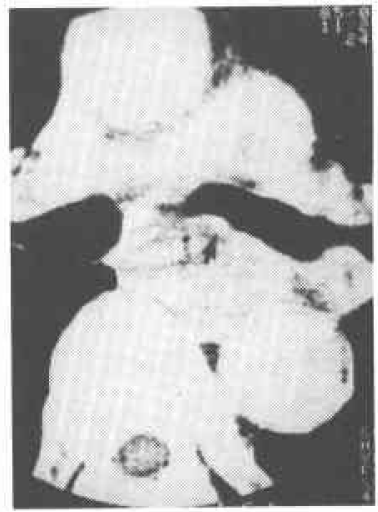

IV. 結 果 b

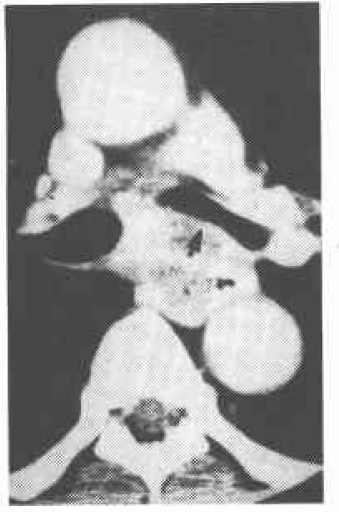

対象とした128例のうち $\mathbf{a}_{3}$ 症例は31症例で，そのう ち2つの蔵器に浸潤を認めたものは 5 例（大動脈と気 管支が 3 例, 大動脈と心のうが 1 例, 気管と気管支が 1 例)であった. $a_{3}$ 臓器の内訳は, 大動脈：15例, 気管： 
困 6 a: 前壁中心の癌腫で心のうとの境界 (矢印) 不明瞭で不整である。b：心のらは強く王排され motion artifact 消失している。いずれる $\mathrm{a}_{3}$ で あった。

a

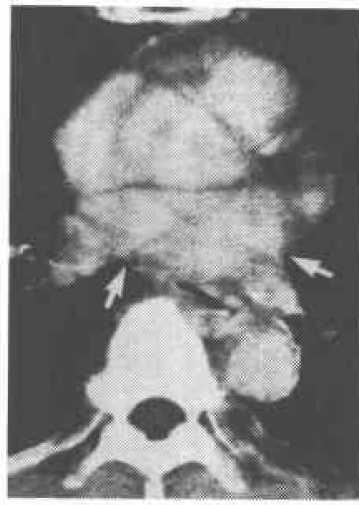

b

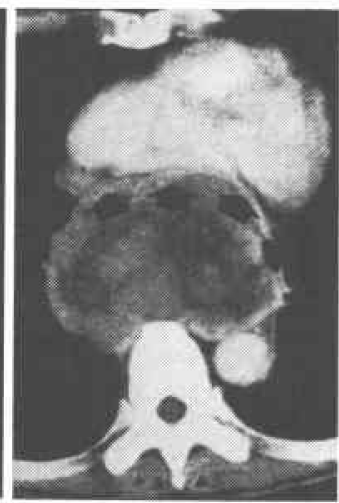

表 2 他臟器漫潤 $\left(\mathrm{a}_{3}\right)$ の正訬率 (128例)

\begin{tabular}{|c|c|c|c|c|c|c|c|}
\hline & $\begin{array}{l}\text { True } \\
\text { Positive }\end{array}$ & $\begin{array}{l}\text { True } \\
\text { Hagat ive }\end{array}$ & $\begin{array}{l}\text { Fitis } \\
\text { Positiven }\end{array}$ & $\begin{array}{l}\text { False } \\
\text { Negative }\end{array}$ & Aceuraty & Stacificity: & Seanitivity \\
\hline$\star$ t & 13 年 & 1.29 & 1 in & 23 & $97.7 \%$ & $897 \%$ & $8 \in 7 \%$ \\
\hline si & 3. & $120=$ & 1. & 0. & 992 , & $992=$ & 100. \\
\hline प्य ह & B. & 119. & 1. & 0. & 902. & $98,2=$ & 100. \\
\hline 403 & $4=$ & 122. & 0. & $2 x$ & $98.4=$ & 100 & $687=$ \\
\hline Hear & & & & & 98.6 & 90,4 & $88.9=$ \\
\hline
\end{tabular}

7 例，気管支：8例，心のう：6例であった，X線型 よりみると,らせん型では49例のうち $a_{3}$ が19例, $38.8 \%$, 鋸歯型では44例中 5 例, $11.4 \%$, 漏斗型では 7 例中 3 例， $42.8 \%$ ，腫瘤型では 5 例中 2 例， $40 \%$ ， その他が 2 例であった。

$a_{3}$ 症例の $60 \%$ がらせん型であり，また漏斗型や腫瘤 型では数は少ないが $\mathrm{a}_{3}$ となる頻度は高かった。 その他 $a_{2}$ 症例は68例, $a_{1}$ 症例は 2 例, $a_{0}$ 症例は27例であった。

この診断基準（表 1 ）による正診率は，全体として overall accuracy $98.6 \%$, specificity $99.4 \%$, sensitivity $86.7 \%$ であった。次いで各蔵器別に検討を行っ た（表 2 ).

1. 大動脈に関して

128例についてその正諩を豖めると, overall accuracy $97.7 \%$, specificity $99.1 \%$, sensitivity $86.7 \%$ で あった.内訳は true positive (TP)13例, true negative (TN) 122例, false positive (FP) 1 例, false negative (FN) 2 例であった. FN 例の 2 例では，いずれもがい わゆる深部浸潤型の癌腫で, 1 例は Imlu 長さ $8 \mathrm{~cm} の$
図 $7 \quad a_{3}$ 食道癌症例. ImIu 長さ $8 \mathrm{~cm}$ の食道癌ではっ きりとした潰場を有せず，CT 上でも大動脈との接 する面は $1 / 4$ 周以下 (矢印の範囲)で $A_{2}$ と誤診した症 例.

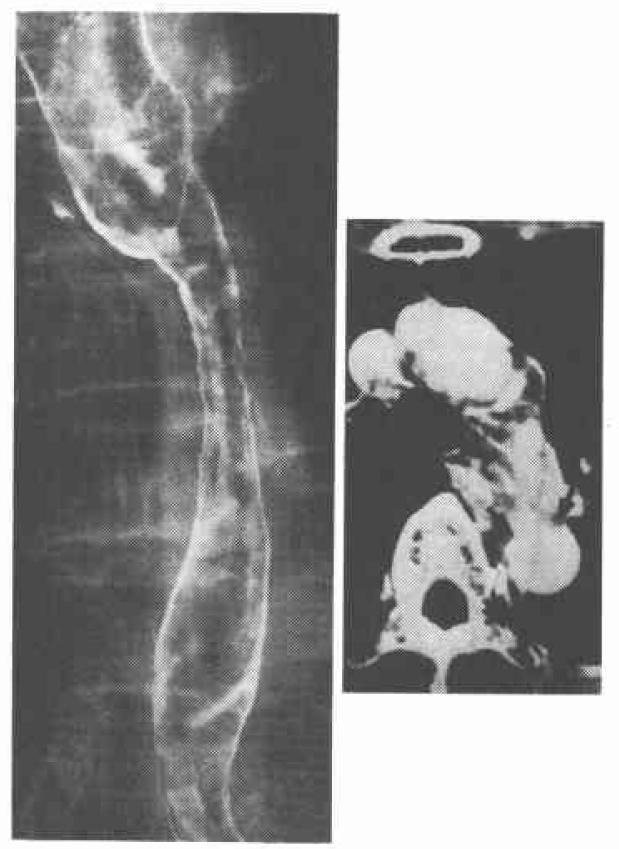

全周性のらせん型の中分化型扁平上皮癌で，も51例 は ImEi 長さ5 $\mathrm{cm}$ の全周性のらせん型の腺表皮癌で あった。これまでの食道 $\mathrm{X}$ 線診断からみても $\mathrm{A}_{2}$ と診 断. さらに CT 像でも大動脈と癌腫の接する面の大き さも,大動脈の約 $1 / 5$ 周であったため, 最終的に $\mathrm{A}_{2}$ と診 断した症例であった（図７）.

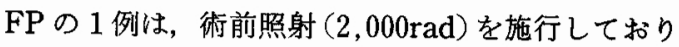
術中所見では $\mathrm{A}_{3}$ であったが, 病理組織学的所見で $\mathrm{a}_{2}$ であった症例であった（図8）。

128例のらち，X線上や CT 上であきらかに $\mathrm{A}_{0}$ であ るすのや $A_{1}$ であるすのを除いた臨床上 $A_{2}$ か $A_{3}$ か診 断が困難であった26症例 (TP 13例，TN 10例，FP 1 例，FN 2 例)についてさらに検討してみた。CT 像か らの診断では, 癌腫と大動脈との接する面の大きさ, 癌腫との間の low density zone の有無などが有力な 診断根拠とされてきたが，このCT 所見だけから診断 すると, 癌腫が大動脈と接する面の大きさが大動脈の 1/5 1/4周の場合, $a_{3}$ 症例は 3 例, $a_{2}$ 症例は 4 例で, 1 / $4 \sim 1 / 3$ 周では $a_{3}: 10$ 例, $a_{2}: 5$ 例, $1 / 3 \sim 1 / 2$ 周では $a_{3}$ : 2 例, $\mathrm{a}_{2}: 2$ 例となり, 確かに接触面が大きくなれば $\mathrm{a}_{3}$ の可能性が高くなるが, FP 例が多くなり sensitivity 
図 $8 \mathrm{a}_{2}$ 食道癌症例. Im 後壁に深い潰浧を有する鋸歯 型の食道癌で, CT 上からる癌腫と大動脈の接触面 が1/4周以上 (矢印の範囲) で $\mathrm{A}_{3}$ と考えられた症例.

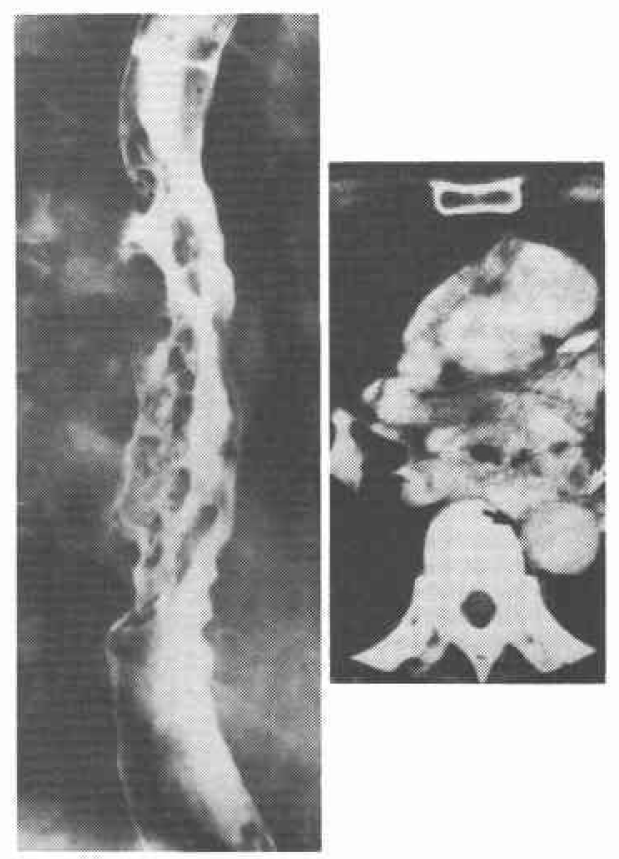

は高いものの specificity は低くなってしまう。また， $a_{2}$ であった11症例のうち正診しえた10例についてX線 学的根拠を調べてみると, 占居部位から診断しえたも の 4 例, 癌腫の発育進展方向より診断しえたもの 4 例, 潰瘍の深さ・周堤の高さより診断しえたもの 2 例で あった. CT 上癌腫と大動脈との接触面が $1 / 5 \sim 1 / 4$ 周 で $a_{3}$ 症例であった 3 例のうち，TPの 1 例はX線上左 後壁に大きな潰瘍を有する鋸歯型の癌腫であった。 FNの 2 例は前述のごとく，はっきりとした潰瘍を認 めず, 癌腫の発育伸展の方向性が判然としなかったた め誤診した症例である. 残りの12例はX線上からも $\mathrm{CT}$ 上からも $\mathrm{A}_{3}$ と診断が一致した症例である.

またCT上の癌腫と大動脈との接する面の大きさと 漫潤の程度とは一定の関係は認められなかった.

2. 気管に関して

TP 7 例, TN 120例, FP 1 例, FN 0 例で, accuracy $99.2 \%$, specificity $99.2 \%$, sensitivity 100\%であった. 1 例だけ FP 例を認めたが,この症例は, 術中所見で癌 腫と気管とは容易に剥離でき, 肉眼的に $\mathrm{A}_{2}$ と診断され た症例であり, 病理組織学的には $\mathrm{a}_{2} \sim \mathrm{a}_{3}$ であった（図 9).

Iu 食道癌は128例中 9 例と症例は少なかったが, $\mathrm{A}_{3}$
因 9 Iu 前壁に大きな潰瘍を有する食道癌で, CT 上 広範囲にわたり気管と接している (矢印の範囲) が,

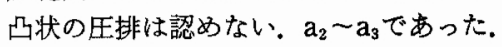

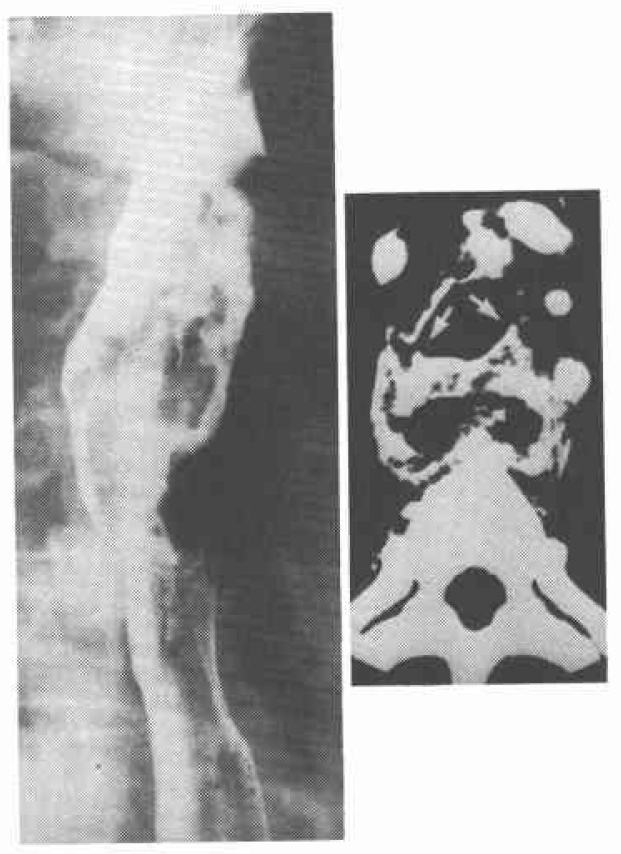

表 3 気管の CT 像と根治度

\begin{tabular}{|c|c|c|c|}
\hline 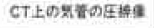 & 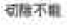 & 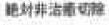 & 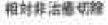 \\
\hline 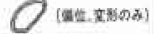 & O列 & D例 & 1 例 \\
\hline (平坦公王㴊) & $0 n$ & $1 " 11$ & $3 n$ \\
\hline (日转的在棈) & $2 \prime \prime$ & $1 " n$ & $0 \prime \prime$ \\
\hline
\end{tabular}

の診断に関しては食道 X線診断它 CT 診断す accuracy は99.2\%と高い正診率であったが，CT 上からは $\mathrm{A}_{3}$ の程度をより詳細に診断でさた。すなおち, 胸部上 部食道は気管膜様部に直接接して位置しており，CT では癌腫による気管の変形や王排像などから浸潤程度 を把握することが他の缄器と比べ容易であり, CT上 癌腫が気管内腔へ凸状に突出していた症例では全例 bypass 手術か絶対非治慗切除となった（表 3). しかし ながら症例（図10）のようにCT 上著明な気管の王排 像を認めたとしても, 筇腫に合併した表在癌のような 症例むあるので, やはり, 食道X線像から癌腫の性状 を見極めることが大切である。

\section{3. 気管支に関して}

TP 8 例, TN 119例, FP 1 例, FN 0 例で, accuracy $99.2 \%$, specificity $99.2 \%$, sensitivity 100\%であった. 
図10 CT 上では腫瘤 ( T ) により気管が著明に压排さ れているが，X線上では腫瘤全体が悪性とは考元に くい.

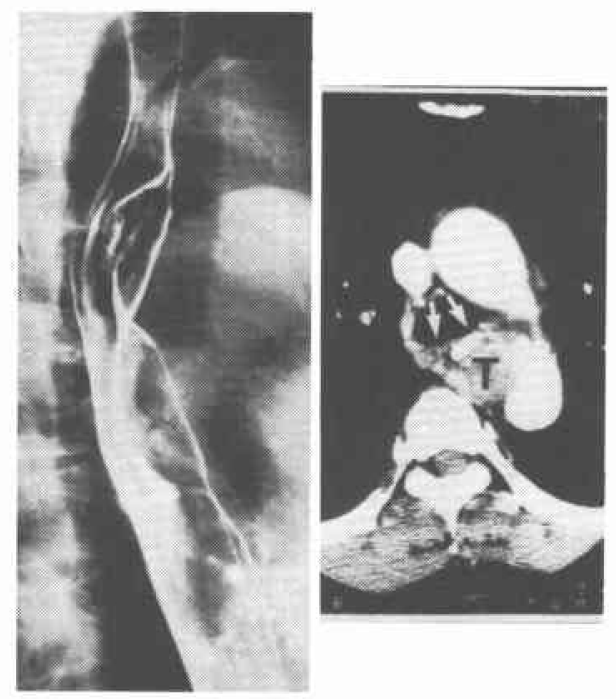

FP 例の 1 例は前述の術前照射施行例で, 術中所見で は $\mathrm{A}_{3}$ であったが病理組織学的検索で $\mathrm{a}_{2}$ であった症例 である。

$\mathrm{CT}$ 上，気管支壁が癌腫により著明に凸状に圧排さ れている症例や明らかに壁の凹凸不整を示した症例は 6 例あり，全例とも絶対非治㦄切除術に終っている. 一方，気管支壁のわずかな不整，直線化，狭細化を認 めた症例では，CT 上だけから $\mathrm{A}_{3}$ の診断を下すことは 困難であった，CT 上気管支壁のわずかな不整，直線 化，狭細化を呈した 6 症例のらち， $a_{3}$ であったのは 2 例，残りの 4 例は $\mathrm{a}_{2}$ であった。このような症例こそ食 道X線像から，居部位，壁在性，伸展方向などを調べ ることが有用であった（図11，12）。

つまり, 主要占居部位が Im で病変が全周性か前壁 中心の癌腫で，少なくとも周堤が気管分岐部の高さよ りも口側上方まで浸潤しているものでは全例 $\mathbf{a}_{3}$ であ ク, 逆に, 後壁中心のものや, 癌腫が Iu まで及んでい ないものでは全例 $\mathrm{a}_{2}$ の症例であった。このような所見 を有する $a_{3}$ 症例では相対非治癒切除が行われた。

食道X線像だけからの $\mathrm{A}_{3}$ の診断でも， accuracy $98.4 \%$, specificity $98.3 \%$, sensitivity $100 \%$ と良好な 結果を得たが，CT ではさらに気管支への浸潤の程度 や範囲が明瞭となった（表 4 ）。

4.心のうに関して

TP 4 例, TN 122 例, FP 0 例, FN 2 例で, accuracy
図11 CT 上気管支壁の直線化を認めたが，X線上 Im 左側中心のラセン型の食道癌で $\mathrm{a}_{2}$ であった（ヒは気 管分岐部の高さ)

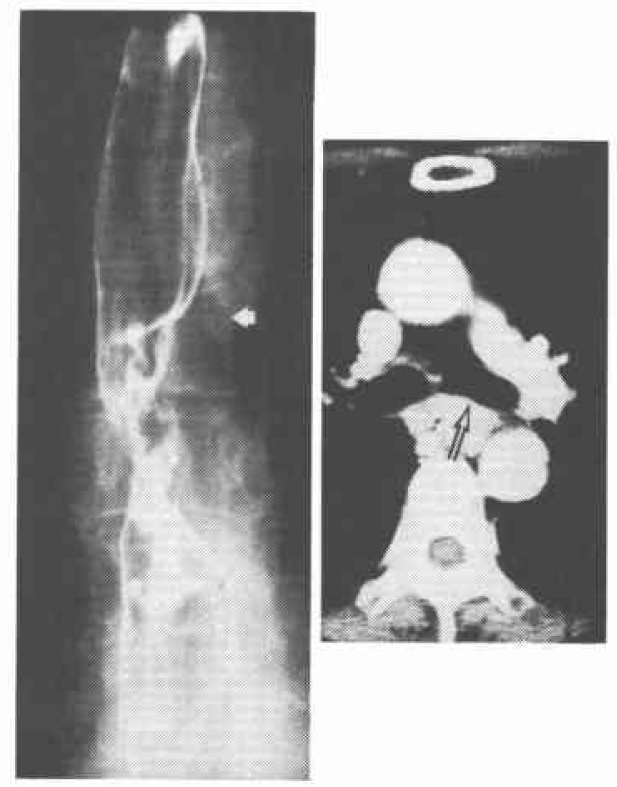

図12CT 上は前症例と同様に気管支壁の直線化を認 めたが，X線上 ImIu 右前壁中心のラセン型の食道 癌で $a_{3}$ であった（なは気管分岐部の高さ）

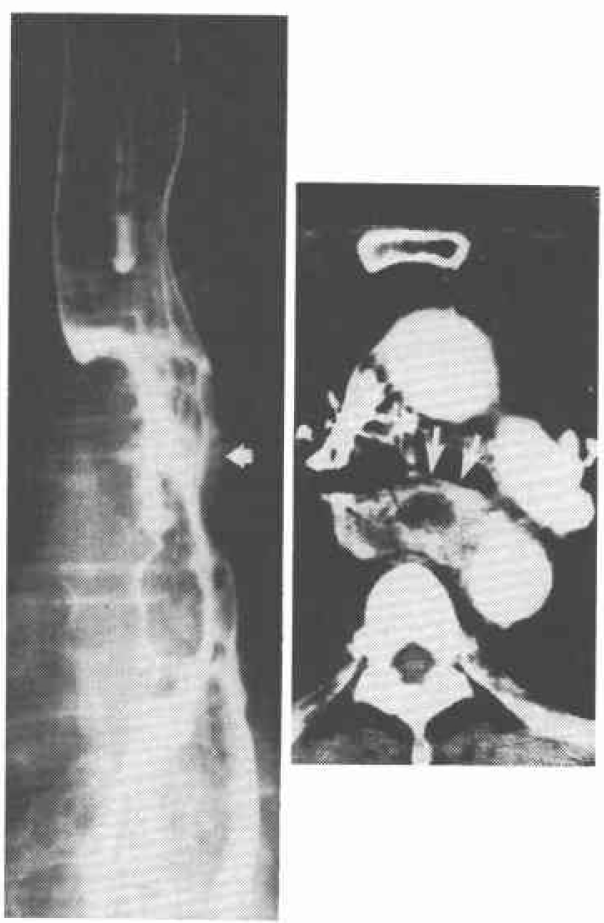


表 4 気管支の CT 像と根治度

\begin{tabular}{|c|c|c|}
\hline 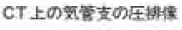 & 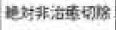 & 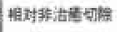 \\
\hline 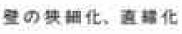 & 0 (例 & 2 洌 \\
\hline 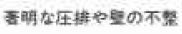 & $6 \prime \prime$ & $0 " 11$ \\
\hline
\end{tabular}

図13 両者とも心のうとの境界（矢印）は明瞭にみ兄 るが, $a$ は $a_{2}$ 症例, bは $a_{3}$ 症例であった。
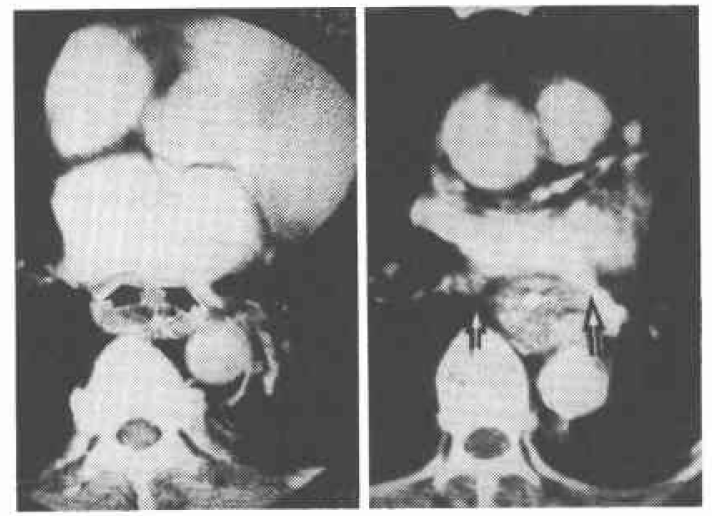

図14 両者とも心のうとの境界（矢印）は不明瞭であ るが, $a$ は $a_{2}$ 症例, bは $a_{3}$ 症例であった. a

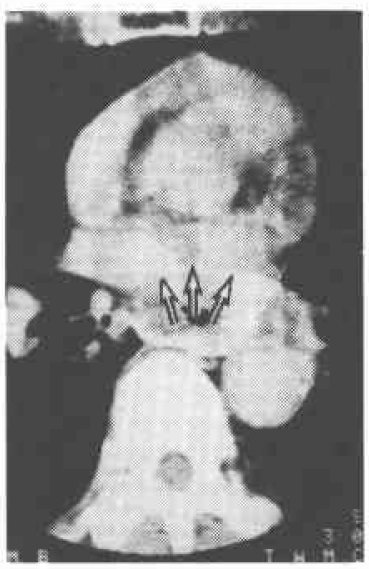

b

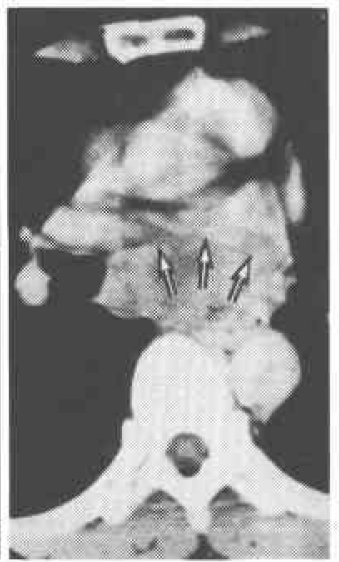

98.4\%, specificity 100\%, sensitivity $66.7 \%$ あっあた. FN の 2 例はいずれも境界明瞭でその辺縁も平滑であ り，X線上でも $\mathrm{A}_{2}$ と診断した症例であった（図13）。

Sensitivity が66.7\% と他の臓器と比べ, 正診率は 坌った.これは心拍動の影響によるもので, CT 上 $\mathrm{a}_{2}$ の 症例と $\mathrm{a}_{3}$ の症例が同様の所見を呈し癌腫が小さい時
期に診断することは困難であった(図14)，癌腫が大き くなり，心のらが強く圧排され，motion artifact が消 失したり，心のうと癌腫との境界が明らかに不規則と なることなどの所見を呈すれば診断は容易である。

心拍動の影響を受けないような新しいCT 装置の改 良などが診断能の向上には必要であると考方る。

\section{V. 総括ならびに考察}

術前に食道癌の周囲臓器への浸潤(とりわけ, 大動 脈，気管，気管支）や胸部腹部リンパ節の転移や肝転 移の有無などを知ることは，食道癌治療方針の決定， 術式の選択，術中リンパ節郭清，さらには術前術後の 照射の決定や照射野の設定など，あるいは予後の判定 などの観点から重要である2) 9)24) 26)。これまでに，よ

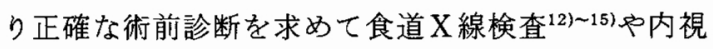

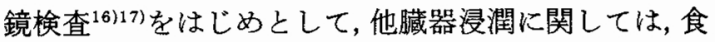
道粘膜下造影法 ${ }^{18)}$, 奇静脈造影法 ${ }^{19)}$. 21), 気稀隔撮影法, 食道動脈造影法 ${ }^{27)}$, 胸管造影法, 縦隔鏡検査 ${ }^{28)}$ などが試 みられてきた。

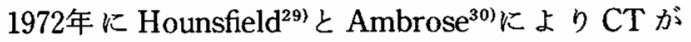
開発され, 以後新しいCT 装置の開発改良に伴い全身 のCT 検査が行われるようになってきた。 また第 2 ， 第 3 世代の機種の出現により, より解明な画像が得ら れるようになりその診断能は向上してきた ${ }^{3132)}$.

CTによる食道癌の他臓器浸潤に関寸る報告は, 1979年には Daffner ら ${ }^{33)}$ が, 1981年には Coulomb ら ${ }^{34)}$ や Moss ら ${ }^{35}$ 唯行っており，いずれもCT 診断の有用 性について述べている.

1983年にはPicus ら ${ }^{23)}$ がとくに大動脈に関しての $\mathrm{A}_{3}$ の診断について, 具体的な診断基準を retrospectiveな見地から報告した。つまり，癌腫が大動脈の1/ 4周，90以上とり井んでいる場合には $80 \%$ が $\mathrm{a}_{3}$ であっ たと報告している。またThompson ら ${ }^{36)}$ は, 気管, 気 管支に対しては93\%，大動脈に対しては90\%の正診率 であったことを報告している，気綖隔 CTでは，大久 保ら ${ }^{37)}$ は94\%，木村 ${ }^{38}$ は96\%の正診率であったと報告 している、㵴器別にみると, 大久保ら ${ }^{371}$ は, 大動脈に関

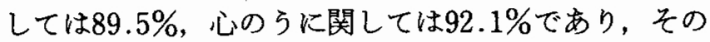
診断基準は気縦隔に打いて, 癌腫と相手臓器が分離し なければ $\mathrm{A}_{3}$ と診断し, 癒着性変化のあるすのではおの ずと診断に限界があるとし，気管，気管支に関しては 報告していない，不村 ${ }^{38)}$ は食道癌の浸潤頻度の高い大 動脈，気管，気管支，心のうについて検討を行った。 大動脈に関しては，接触角が $75^{\circ}$ 以上を浸潤ありとし， 気管, 気管支, 心のうに対しては, 癌腫と接触する葴 
器の壁や辺縁の不整, 変形, 内腔の凹凸圧排像の有無 などを診断基準とした。また，新しい試みとして，リ ピオドールを食道粘膜下に注入後 CT 検査を行い壁外 伸展の状態をより正確に知ることが可能となったとの 報告39) むるが，リピオドールにて artifact が生じた り, 腫瘍肛門側の病変までは十分に抽出できないなど の問題点も指摘されている.

今回, 食道X線診断と $\mathrm{CT}$ 診断とを組み合せ, 大動 脈, 気管, 気管支, 心のうについてそれぞれの診断基 準を設け,この 1 年10カ月間に手術を施行された128例 について検討を行った，その成績は全体として， overall accuracy $98.6 \%$, specificity $99.4 \%$, sensitivity $88.9 \%$ となり, X線像だけからの診断率, overall accuracy $97.5 \%$, specificity $98.7 \%$, sensitivity $79.4 \%$ と 比べ, とくに sensitivityに打いて有意に高かった。

大動脈に関してはとくに食道X線所見と CT 所見か らの総合診断が有用であった.しかし，CT 上の所見と 浸潤の程度とは一定の関係は認められなかった。. $\mathrm{A}_{3}$ 食

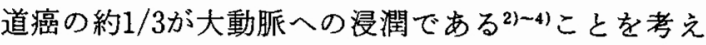
ると今後，より鋭敏な画像診断が必要となろう。

気管に関しては, Iu で全周性か前壁中心の癌腫で, $\mathrm{CT}$ で癌腫が気管内腔へ突出している所見が $\mathrm{A}_{3}$ の診 断に重要である。ささらに気管と癌腫の接する面が気管 の1/3周以上あれば,姑息手術におわる可能性が高いと 考光られる。

気管支に関しては，X線診断の正診率は高く accuracy $98.4 \%$, specificity $98.3 \%$, sensitivity $100 \%$ で あった. Im 中心で Iu まで及んでいる全周性のらせん 型や前壁に深い潰慯をもつ鋸歯型のものや軸偏位を認 める症例では $\mathrm{A}_{3}$ の可能性が高い,ささらにCT 所見は浸 潤の程度や範囲を推察するのに有用であった. CT 上, 気管支壁が著明に凸状に圧排されていたり，明らかに 壁が凹凸不整を示した症例では絶対非治癒切除に終っ て和り，気管支壁の直線化や狭細化を呈した症例では 相対非治癒切除であった。

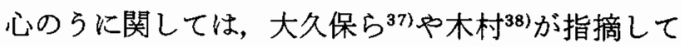
いるように，心拍動のため気縦隔 CT も診断の向上に 役に立たないようである. 今回の検索結果です FN 例 が多くなったが，これは症例でも示したように， $\mathrm{a}_{2}$ と $\mathrm{a}_{3}$ の症例の CT 所見に差が認められず，また $\mathrm{a}_{2}$ の症例 が多かったため, $\mathrm{A}_{2}$ と診断せざるをえなかったためで ある. 食道X線像です CT 像です癌腫が大きくなれば 診断は容易であるが，現在のところ，心のうに関して の $\mathrm{A}_{3}$ の診断には限界があり, 今後, heart gated CTな
どの新しい工夫やさらに進んだ CT 装置の改良などが 必要となろう。

\section{V. 結 語}

1983年 6 月から1985年 3 月までに検討しえた 128 症 例の胸部食道癌症例について, 他臓器浸潤の診断を食 道 X線検查と CT 検查から，診断基準を設け臨床的検 討を行い以下の結果を得た.

1. X線診断と CT 診断とを組合せて診断を行らこ とにより, overall accuracy $98.6 \%$, specificity $99.4 \%$, sensitivity $88.9 \%$ と食道X線診断や CT 診断 だけからの診断に比べ，有意にその診断能の向上をみ た.

2. 大動脈に関しては, overall accuracy $97.7 \%$, specificity $99.1 \%$, sensitivity $86.7 \%$ であり，X線所 見とCT 所見の総合診断が有用であった。

3. 気管に関しては，X線診断もCT 診断も overall accuracy が99.2\%と高い正診率であったが, CT では 癌腫による気管の变形や圧排像などから浸潤の程度を より詳細に診断できた。

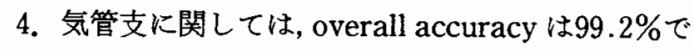
あった、X線診断だけです $98.4 \%$ と良好な結果であっ たが，CTではさらに気管支への浸潤の程度や範用が 明瞭となった。

5.心のうに関しては, overall accuracy は98.4\%で あったが, sensitivity でみると $66.7 \%$ となり，その診 断には限界があり正診率も他の藏器と比べ劣った。

稿を終るに臨み，御校閲を賜った東京女子医大消化器病 センター羽生富士夫教授に深甚なる感謝の意を表すととも に, 終始御指導, 御教示を頂いた東京女子医大消化器病セン ター山田明義教授, 東京医科歯科大学第 1 外科遠藤光夫教 授，ならびに本研究の遂行に御協力を賜った東京女子医大 放射線科河野 敦講師, 東京女子医大消化器病センター井 手博子助教授, 吉田 操講師, 磯部義憲講師, 食道研究班各 位に深謝致します。

\section{文献}

1）食道疾患研究会編：臨床病理食道癌取り扱い規 約. 第 5 版, 東京, 金原出版, 1976

2) 飯塚紀文, 平田克治, 渡辺 寛: 他臓器に浸潤の及 んだ食道癌の切断手術。日胸外会誌 $28: 607$ $-610,1980$

3）木下祐宏, 遠藤光夫: 胸部食道癌と他喴器合併切 除. 胸部外科 $33: 828-834,1980$

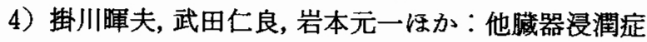
例の外科的治療. 胸部外科 $33: 810-814,1980$

5）飯塚紀文: $A_{3}$ 食道癌の外科的治療. 胸部外科 $33: 822-827,1980$ 
6）佐藤 博, 磯野可一, 小野田昌一ほか：食道癌払大 合併切除。外科治療 $23: 399-404,1981$

7）遠藤光夫, 山田明義, 吉田 操ほか：胸部食道癌の 外膜浸潤とリンパ節転移。臨成人病 $13: 737$ $-741,1983$

8）遠藤光夫，山田明義, 井手博子ほか：胸部食道癌の 切除郭清術式. 外科治療 $49: 25-31,1983$

9）河原英之, 藤田博正, 小田桐重遠注か：大動脈合併 切除を伴う食道癌切除例の 1 例. 日外会誌 86 ： 1546-1551，1985

10）村田洋子, 井手博子, 秋本 伸ほか：食道癌におけ る腹腔内転移リンパ節の超音波診断の検討. 日消 外会誌 $14: 1005-1015,1981$

11）久米川啓：内視鏡的超音波検查に上る食道癌壁深 達度, リンパ節転移の臨床的研究. 日消外会誌 $18: 1774-17,1985$

12）山田明義, 小林誠一郎, 井手博子ほか：食道癌の予 後を左右するX線学的分類. 臨放線 $27: 1057$ $-100,1982$

13）山田明義, 小林誠一郎, 遠藤光夫 : 食道癌一質的診 断とその限界. 画像㗒断 $2: 616-625,1982$

14）山田明義, 小林誠一郎, 荻野知巳ほか：食道癌の $\mathrm{X}$ 線からみた治療方針。臨放線 25:9-20，1980

15）植松貞夫：食道癌深達度の診断. 臨放線 27 ： 1037-1047, 1982

16）赤倉一郎, 掛川睴夫, 村上久患ほか：食道ファイ バースコープ. 外科診療 $8 ； 35-41,1966$

17）遠藤光夫, 山田明義, 井手博子ほか：食道癌早期診 断の進歩. 消外七ミナー 7:7一20, 1982

18）千葉 淳, 坪井正碵, 芳賀甚市ほか：食道癌手術適 応に関する食道粘膜下造影像の意義. 日外会誌 $78: 509-515,1977$

19）山田明義：胸部食道癌に対する奇静脈造影法の診 断的価値に関寸る研究. 千葉医誌 $43: 71-104$, 1967

20）牧野正興：食道癌における逆行性奇静脈造影の臨 床的研究。日医放線会誌 $35: 394-429,1975$

21) Segarra MS, Cardus JC: The value of azygography in carcinoma of the esophagus. Surg Gynecol Obstet $141: 248-250,1975$

22) Veccio TG: Predictive value of a single diagnostic test in unselected populations. N Engl J Med 274 : 1171-1173, 1966

23) Picus D, Balfe DM, Koeher RE et al: Comoputed tomography in the staging of esophageal carcinoma. Radiology $146: 433-435$, 1983

24) Beaty JD, DeBoer G, Rider WD et al: Carcinoma of the esophagus : Pretreatment assessment, correlation of radiation treatment parameters with survival, and identification and management of radiation treatment failure. Cancer $43: 2254-2267,1979$

25) Yamada A: Radiologicas assessment of resectability and prognosis in esophageal carcinoma. Gastrointest Radiol 4 : 213-218, 1979

26) Schuchman GF, Heydorn WH, Carter SC et al : Treatment of esophageal carcinoma - A retro. spective review - . J Thorac Cardiovasc Surg $79: 67-73,1980$

27）田之畑修朔：食道癌における食道動脈造影に関す る臨床的研究一，固有食道動脈造影を中心として 一. 日医放線会誌 $37: 103-124,1977$

28）高橋啓泰：食道疾患に対寸る縦隔鏡検査一食道癌 を中心として一、日胸外会誌 $30: 342-346,1982$

29) Hounsfield DN: Computerized transverse axial scanning (Tomography) : Part. 1. Description of system. Br J Radiol 46 : 1016-1022, 1973

30) Ambrose J: Computerized transverse axial scanning (Tomography): Part. 2. Clinical applications. Br J Radiol 46 : 1023-1047, 1973

31) Schellinger D: Eary clinical experience with the ACTH scanner. Radiology $114: 257-261$, 1975

32) Alfidi RJ, Haaga J, Meaney $T F$ et al : Computed tomography of the thorax and $a b$ domem : A preliminary report. Radiology 117 : 257-264, 1975

33) Daffner RH, Halber HD, Postlethwait RW et al : CT of the esophagus: 2. Carcinoma. AJR $133: 1051-1055,1979$

34) Coulomb M, Lebas JF, Sarrazin R et al: Computed tomography and esophageal carcinoma. J Radiol 62: 475-487, 1981

35) Moss AA, Schnyder P, Thoeni RF et al: Esophageal carcinoma pretherapy staging by computed tomography. AJR $136: 1051-1056$, 1981

36) Thompson WM, Halvorsen RA, Foster WL et al: Computed tomography for staging esophageal and gastroesophageal cancer: Revaluation. AJR 141 : 951-958, 1983

37）大久保幸一, 浜田麻美, 西沢由香理ほか：食道癌に おけるCT-PMGCTによる検討一, 日医放線会 誌 $42: 740-748,1982$

38）木村正幸：食道癌におけるCT の有用性に関する 研究一特に気綎隔 CT を中心にして，日消外会誌 $18: 607-613,1985$

39）田中敬正, 沢田 敏, 村田貴史はか：リピオドール の粘膜下注入による食道癌の CT 像の有用性. 臨 放線 $29: 571-576,1984$ 